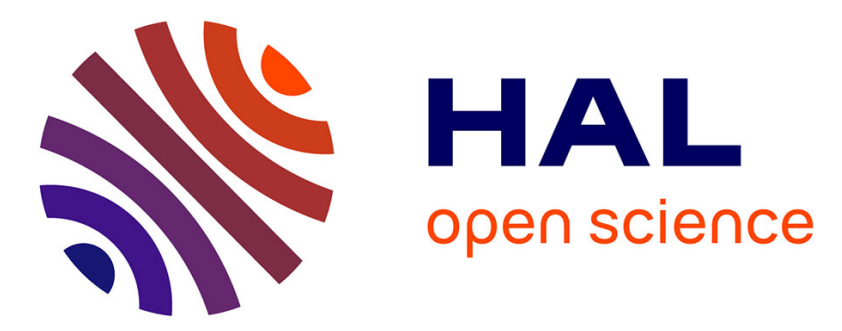

\title{
Capacity of soil amendments in lowering the phytoavailability of sludge-borne zinc
}

Michel Mench, Alain Manceau, Jaco Vangronsveld, Herman Clijsters, Bernard Mocquot

\section{- To cite this version:}

Michel Mench, Alain Manceau, Jaco Vangronsveld, Herman Clijsters, Bernard Mocquot. Capacity of soil amendments in lowering the phytoavailability of sludge-borne zinc. Agronomie, 2000, 20 (4), pp.383-397. 10.1051/agro:2000135 . hal-00886054

\section{HAL Id: hal-00886054 https://hal.science/hal-00886054}

Submitted on 1 Jan 2000

HAL is a multi-disciplinary open access archive for the deposit and dissemination of scientific research documents, whether they are published or not. The documents may come from teaching and research institutions in France or abroad, or from public or private research centers.
L'archive ouverte pluridisciplinaire HAL, est destinée au dépôt et à la diffusion de documents scientifiques de niveau recherche, publiés ou non, émanant des établissements d'enseignement et de recherche français ou étrangers, des laboratoires publics ou privés. 


\title{
Original article
}

\section{Capacity of soil amendments in lowering the phytoavailability of sludge-borne zinc}

\author{
Michel J. Mench ${ }^{\mathrm{a} *}$, Alain MANCEAU ${ }^{\mathrm{b}}$, Jaco VANGRONSVELD ${ }^{\mathrm{c}}$, \\ Herman CliJsTERs ${ }^{\mathrm{c}}$, Bernard MOCQUOT $^{\mathrm{a}}$
}

\begin{abstract}
a INRA Agronomy Unit, Bordeaux-Aquitaine Research Centre, BP 81, 33883 Villenave d'Ornon Cedex, France
${ }^{\mathrm{b}}$ Environmental Geochemistry Group, LGIT-IRIGM,University of Grenoble and CNRS, BP 53X, 38041 Grenoble Cedex 9, France

${ }^{\mathrm{c}}$ Limburgs Universitair Centrum, Department SBG, Universitaire Campus, Building D, 3590 Diepenbeek, Belgium
\end{abstract}

(Received 25 January 1999; revised 12 April 2000; accepted 20 April 2000)

\begin{abstract}
One way to reduce the phytoavailability of an excess of metals such as zinc in soil is through the addition of amendments. The effectiveness of inorganic materials such as basic slags, magnetite, maghemite, hematite, birnessite, hydrous manganese oxide, steel shots, and beringite, was evaluated in a pot experiment with a coarse sandy soil contaminated by sludge-borne zinc. Zinc extractability and phytoavailability were investigated using single soil extraction by $0.1 \mathrm{M}$ calcium nitrate and vegetation experiments with dwarf bean (Phaseolus vulgaris L.) and ryegrass (Lolium multiflorum). A phytotoxicity test based on the activities of enzymes involved in the stress metabolism caused by toxic $\mathrm{Zn}$ concentrations in the primary leaves of dwarf beans was also performed. Based on the addition rate, birnessite $\left(10 \mathrm{~g} \cdot \mathrm{kg}^{-1}\right.$ soil, dry weight DW) resulted in the maximum decrease in extractable $\mathrm{Zn}$ from the contaminated soil. Beringite gave similar results but at $50 \mathrm{~g} \cdot \mathrm{kg}^{-1}$ soil DW. Birnessite and beringite treatments were the most effective to reduce $\mathrm{Zn}$ assimilation by dwarf bean, and in consequence phytotoxicity. Subsequent harvests of ryegrass confirmed the beringite effect on $\mathrm{Zn}$ uptake 5 months following the soil treatment. For birnessite, Zn availability to ryegrass shoots increased however at the third harvest and reached the level of the untreated Zn-contaminated soil.
\end{abstract}

beringite / iron oxide / manganese oxide / soil remediation / zinc

Résumé - Capacité d'amendements à diminuer la phytodisponibilité du zinc issu de boues urbaines dans un sol. Amender le sol est une des voies possibles pour diminuer l'exposition excessive des racines des végétaux aux métaux comme le zinc. L'efficacité de matériaux minéraux, e.g. scories phosphatées, magnétite, maghémite, hématite, birnessite, oxyde de manganèse hydraté, grenaille d'acier et béringite, pour diminuer la phytodisponibilité de Zn a été étudiée en vase de végétation avec un sol sableux contaminé par des apports de boues urbaines. L'extractabilité et la phytodisponibilité de $\mathrm{Zn}$ ont été déterminées à l'aide d'une extraction sélective au nitrate de calcium 0,1 M et de cultures de végétaux, haricot nain (Phaseolus vulgaris L.) et raygrass (Lolium multiflorum). Un test de phytotoxicité, basé sur les

Communicated by Marco Trevisan (Perugia, Italy)

* Correspondence and reprints

Mench@bordeaux.inra.fr 
activités d'enzymes permettant à la plante de compenser des effets négatifs du zinc, a été réalisé avec les feuilles primaires du haricot. D'après le taux d'apport, la birnessite $\left(10 \mathrm{~g} \cdot \mathrm{kg}^{-1} \mathrm{sol} \mathrm{sec}\right)$ a diminué le plus la quantité de Zn extractible du sol. La béringite produit un effet similaire, mais avec un taux de $50 \mathrm{~g} \cdot \mathrm{kg}^{-1} \mathrm{sol} \mathrm{sec}$. Birnessite et béringite sont les traitements les plus efficaces pour diminuer le prélèvement du zinc par le haricot et la phytotoxicité. Trois coupes successives du raygrass ont montré que la diminution du prélèvement de $\mathrm{Zn}$ par la plante après traitement du sol par la béringite persiste sur 5 mois. Avec la birnessite, l'accumulation de $\mathrm{Zn}$ dans les parties aériennes du raygrass augmente à la troisième coupe, redevenant similaire à celle des plantes cultivées sur le sol non traité.

beringite / oxyde de fer / oxyde de manganèse / remédiation du sol / zinc

\section{Introduction}

For many years, $\mathrm{Zn}$ has ranked fourth in annual world metal consumption [1,4]. This often results in excessive build-up of anthropogenic $\mathrm{Zn}$ in topsoils caused by various activities such as industry without efficient emissions' controls [5, 25, 34], long-term use of organic wastes (sewage sludge, slurry) [2, 11, 19], and of sediments dredged from ship canals and rivers [1]. Increase of $\mathrm{Zn}$ in soil may create an environmental problem due to its persistence in the environment, mobility, bioaccumulation and/or phytotoxicity. Consequently, a report on soil quality by the Commission of the European Community focused attention on $\mathrm{Zn}$ as a soil contaminant [14]. In higher plants, the visual symptoms of Zn-toxicity are often chlorosis and stunted growth, and inhibition of root growth is usually manifested [10]. Critical concentrations in leaves above which the yield decreases are often at $200 \mathrm{mg} \cdot \mathrm{kg}^{-1}$ dry matter (DM) $[22,31]$. Toxic $\mathrm{Zn}$ concentrations inhibit physiological processes such as photosynthesis, phloem translocation, and transpiration [13, 31]. Soil reclamation reducing $\mathrm{Zn}$ availability is required in two situations: (i) for safer food production and maintenance of crop yield in slightly polluted soils; and (ii) for the reclamation of highly-polluted soils that are often denuded of vegetation. Both ecological and engineering technologies have been developed for treating metal-contaminated soils $[12,20,25,27$, 35]. Metal in situ immobilisation may be a more realistic and cost-effective alternative, especially for vast industrial sites and surrounding rural land, dumping grounds, and sludge-treated soils highly contaminated due to historical pollution [35].
Both physico-chemical and biological soil factors control Zn bioavailability. Therefore, a logical solution for managing $\mathrm{Zn}$-polluted soil, and especially to minimise plant uptake, involves a twoway approach [9]. First, plant species differ in both metal uptake and sensitivity to metals. Monocotyledonous crops such as corn and most grasses can generally tolerate higher soil $\mathrm{Zn}$ concentrations compared to dicotyledonous plants. Differences among cultivars in $\mathrm{Zn}$ uptake have also been described $[10,18]$. On the other hand, soil properties controlling $\mathrm{Zn}$ phytoavailability are: soil $\mathrm{pH}$, organic matter, cation exchange capacity (CEC), clay type and amount, oxides and redox potential [1, 2]. Amelioration of Zn-contaminated soils is usually based on the application of lime and/or organic matter $[8,12,20]$. In most cases, but especially in acidic sandy soils, lime and phosphate (phospho-gypsum, basic slag) are effective in lowering Zn uptake by plants. However, the sustainability of the liming effect is generally short or its effect is less than expected [27, 35]. Excessive increases in $\mathrm{pH}$ may enhance metal complexing by soluble organic matter, desorption of toxic oxyanions in mixed metal systems, and nutrient deficiency. Candidates for inorganic amendments are oxides, silicates and phosphates. Several materials have been shown to decrease either $\mathrm{Zn}$ mobility or $\mathrm{Zn}$ availability after a single application. Beringite, a cyclonic ash provided by the fluidized bed burning of coal refuse from the former coal mine in Beringen, Belgium, can restore plant growth by both reducing $\mathrm{Zn}$ exposure at the root level and increasing $\mathrm{Ca}$ and $\mathrm{Mg}$ nutrition [27, 33, 34]. Zinc sorption on hydroxyapatite surface has been reported [37]. Fe-bearing material such as steel shots, hydrous Mn oxides, apatite and zeolites have been 
found to reduce $\mathrm{Zn}$ uptake by plants in mesocosms $[12,17,25,27,28]$. A comparison of the $\mathrm{Zn}$ immobilising effect of hydrous oxides and alkaline materials was unavailable from a literature review, except for a study on Fe-rich ${ }^{\mathrm{TM}}$, lime and apatites $[12,27]$. Few information is available on the relative effectiveness of soil amendments in decreasing the phytoavailability of sludge-borne $\mathrm{Zn}$. Therefore, this study is aimed at comparing the capacity of Fe and Mn oxides, and of three alkaline materials for the abiotic remediation of a soil contaminated with sludge borne $\mathrm{Zn}$.

Zinc has accumulated in excess in a coarse sandy soil due to applications of sewage sludge at the INRA Couhins experimental farm, Bordeaux, France [19]. As a result, Zn phytotoxicity occurred on sensitive plant species such as dwarf bean. A immobilising treatment was developed at laboratory scale to render sludge-borne $\mathrm{Zn}$ less mobile in this soil and to reduce $\mathrm{Zn}$ uptake by plants. Amendments tested on a laboratory scale were iron oxides, manganese oxides, cyclonic ashes (beringite), basic slags and lime. Zn extractability and phytoavailability were investigated using single soil extraction by $0.1 \mathrm{M}$ calcium nitrate and vegetation experiments with dwarf bean and ryegrass. The activities of enzymes such as peroxidases and several NADPH producing enzymes of the intermediary metabolism were determined in the primary leaves of dwarf bean to test the beneficial effect of amendments on plant metabolism.

\section{Materials and methods}

\subsection{Soils and amendments}

Soils were sampled in the 0 to $20 \mathrm{~cm}$ top layer of two plots located in a long term field trial with sewage sludge applications on an Arenic Udifluvent soil at the INRA Couhins experimental farm, Bordeaux, France. This soil was developed on colluvial material, and was initially acidic $\left(\mathrm{pH}_{\text {water }}=5.5\right)$. The experiment has been described previously [19]. High $\mathrm{Zn}$ content had built up in the contaminated plot due to the application of
Table I. Main characteristics of the control (AMB0) and Zn-contaminated (AMB100) soils.

\begin{tabular}{lcc}
\hline & AMB0 & AMB100 \\
\hline Sand $\left(\mathrm{g} \cdot \mathrm{kg}^{-1}\right)$ & 867 & 811 \\
Silt $\left(\mathrm{g} \cdot \mathrm{kg}^{-1}\right)$ & 88 & 126 \\
Clay $\left(\mathrm{g}^{-1} \mathrm{~kg}^{-1}\right)$ & 45 & 63 \\
Organic matter $\left(\mathrm{g} \cdot \mathrm{kg}^{-1}\right)$ & 21 & 42 \\
$\mathrm{C} / \mathrm{N}$ & 11.2 & 9.1 \\
$\mathrm{pH}($ water $)$ & 5.4 & 5.8 \\
C.E.C. (Metson) & & \\
(cmol $\cdot \mathrm{kg}^{-1}$ soil DW) & 3.3 & 9.4 \\
& & \\
Soil metals $\left(\mathrm{mg} \cdot \mathrm{kg}^{-1}\right.$ soil DW) & & \\
(aqua regia extract) & & \\
& & \\
$\mathrm{Cd}$ & 0.3 & 5.7 \\
$\mathrm{Cu}$ & 14 & 67 \\
$\mathrm{Cr}$ & 6.8 & 23 \\
$\mathrm{Fe}$ & 2807 & 9313 \\
$\mathrm{Mn}$ & 33 & 1797 \\
$\mathrm{Ni}$ & 2.4 & 31 \\
$\mathrm{~Pb}$ & 18 & 189 \\
$\mathrm{Zn}$ & 19 & 1074 \\
\hline
\end{tabular}

$100 \mathrm{mg}$ sludge DW.ha ${ }^{-1}$ every 2 years since 1974 (Tab. I). The main characteristics of the Zn-contaminated soil (so-called untreated soil below, and abbreviated AMB100) and the control soil (AMB0) are listed in Table I.

Nine materials were used to treat the AMB100 soil. Such amendments may induce changes in soil $\mathrm{pH}$ and/or enhance adsorption [27]. Thomas phosphate basic slags (TBS) are a steel metallurgy byproduct (SNST, Puteaux, France). This material contains phosphoric acid $\left(6.6 \% \mathrm{P}_{2} \mathrm{O}_{5}\right)$, lime $(32 \%$ $\mathrm{CaO}), \mathrm{Mg}(10 \% \mathrm{MgO}), \mathrm{Si}(4.7 \%)$ combined as calcium silicophosphates, $\mathrm{Al}(10.3 \%), \mathrm{Mn}(1.6 \%), \mathrm{Fe}$ $(13.4 \%)$ and $\mathrm{Cu}\left(166 \mathrm{mg} \cdot \mathrm{kg}^{-1} \mathrm{DW}\right)$ [28]. Beringite (BER) is a modified aluminosilicate that originates from the fluidized bed burning of coal refuse (mine pile material) from the former coal mine in Beringen, Belgium [27, 34]. Its $\mathrm{pH}$ is strongly alkaline ( 11) as it contains $\mathrm{CaO}$ and $\mathrm{MgO}$ [35]. $\mathrm{SiO}_{2}$ and $\mathrm{Al}_{2} \mathrm{O}_{3}$ represent $52 \%$ and $30 \%$ of the whole product. Illite is the dominant clay present; during the schists heating, kaolinite, chlorite, and 
pyrite disappeared whereas ettringite was formed. Iron oxides includes maghemite $\left(\gamma \mathrm{Fe}_{2} \mathrm{O}_{3}, \mathrm{MAGH}\right)$, magnetite $\left(\mathrm{Fe}_{3} \mathrm{O}_{4}, \mathrm{MAGN}\right)$, and hematite $\left(\alpha \mathrm{Fe}_{2} \mathrm{O}_{3}\right.$, HEM) supplied by Magnox Pulaski Inc, and a Febearing material, steel shot (SS) which contains mainly $\alpha \mathrm{Fe}$ and some impurities [22]. Manganese oxides were a Na-birnessite $\left(\left(\mathrm{Na}_{0.30} \mathrm{Mn}_{0.05}^{\mathrm{II}}\right)\right.$ interlayer $\left(\mathrm{Mn}^{\mathrm{IV}}{ }_{0.74} \mathrm{Mn}^{\mathrm{III}}{ }_{0.21 \square 0.05}\right)$ layer $\left.\mathrm{O}_{\sim 2}\right)$, (BIRN), and a hydrous manganese oxide (HMO). Na-birnessite was prepared at $\mathrm{pH} 9-10$ by oxidising $\mathrm{Mn}(\mathrm{OH})_{2}$ [16]. HMO was synthesised by reducing potassium permanganate in acidic conditions [15]. Calcium oxide ( $\mathrm{CaO}$, Prolabo) with particle size $<0.3 \mathrm{~mm}$ was used in combination with HMO. Seven amendments were given separately in the contaminated soil, whereas $\mathrm{CaO}$ was combined with HMO to neutralise its acidity. Application rates of each amendment except $\mathrm{CaO}$ were based on preliminary bench-scale experiments [27]. The same rate, $10 \mathrm{~g} \cdot \mathrm{kg}^{-1}$ soil DW, was used for HEM, MAGN, MAGH, BIRN and SS. But BER is inefficient at this rate, and was added at $50 \mathrm{~g} \cdot \mathrm{kg}^{-1}$ soil DW. Immobilisation of metals such as $\mathrm{Cd}$ in soil following SS and HMO addition is enhanced at high soil $\mathrm{pH}$ [28]. Therefore, alkaline material such as TBS $\left(2 \mathrm{~g} \cdot \mathrm{kg}^{-1}\right)$ was used alone and in combination with SS $\left(10 \mathrm{~g} \cdot \mathrm{kg}^{-1}\right)$. HMO $\left(10 \mathrm{~g} \cdot \mathrm{kg}^{-1}\right)$ was combined with $\mathrm{CaO}\left(0.5 \mathrm{~g} \cdot \mathrm{kg}^{-1}\right)$. Rates of TBS and $\mathrm{CaO}$ were determined at the bench scale prior to this experiment. Amendments or combinations (e.g. HMOCaO, SSTBS) were separately mixed with AMB100 air-dried soil, previously sieved to $4 \mathrm{~mm}$, by rotating the plastic flask containers. Soil treatments were replicated four times. For each treatment, three pots were cultivated and a fourth one was used for soil extractions. The soil DW inside each pot was $1.2 \mathrm{~kg}$. All potted soils were rehydrated to about $70 \%$ field capacity with a standard nutrient solution containing $250 \mathrm{mg} \mathrm{N}$ $\left(\mathrm{NH}_{4} \mathrm{NO}_{3}\right), 207 \mathrm{mg} \mathrm{K}\left(\mathrm{K}_{2} \mathrm{SO}_{4}\right), 60 \mathrm{mg} \mathrm{Mg}$ $\left(\mathrm{MgSO}_{4}\right)$, and $109 \mathrm{mg} \mathrm{P}\left(\mathrm{Ca}\left(\mathrm{H}_{2} \mathrm{PO}_{4}\right)_{2}\right)$ per $\mathrm{kg}$ soil $\mathrm{DW}$, and placed under greenhouse conditions.

\subsection{Plants}

After one, month to permit reaction with the soil matrix, dwarf beans (cv. Limburgse vroege) were sown ( 3 seeds per pot). Seedlings were grown in a growth chamber $(16 \mathrm{~h}$ light, photosynthetic active radiation set at $350 \mu \mathrm{mol} \cdot \mathrm{m}^{-2} \cdot \mathrm{s}^{-1}, 25{ }^{\circ} \mathrm{C}, 75 \%$ relative humidity; $8 \mathrm{~h}$ darkness, $20{ }^{\circ} \mathrm{C}$ ). After sowing, the soil water status was maintained at $50 \%$ field capacity by adding deionised water. Bean plant organs (i.e. primary leaves, shoots, and roots) were harvested after a two week growing period. Shoot length, fresh and dry weight of the aerial parts, primary leaf area, and chlorophyll content (Minolta SPAD chlorophyllmeter) were determined. Potted soils were maintained at $50 \%$ of the field capacity, and fertilised again with half of the initial amount of nutrient solution. After a two week stabilisation period, a hybrid ryegrass (cv. Augusta) was sown in the pots $(1 \mathrm{~g}$ of seeds per pot). Ryegrass was harvested three times at four week intervals during its growth period. After each harvest, half of the initial amount of nutrient solution was supplied to the pots.

\subsection{Soil analysis}

Aliquots of potted soils without plant were collected. For each treatment, the potted soil was rehomogenised and then broken up to make replicates. In judging $\mathrm{Zn}$ availability, only the small proportion of total $\mathrm{Zn}$ in the soil available to plant is relevant. One way, especially in comparative studies, is to use the water-soluble and exchangeable fractions in soil as an index of the phyto-available fractions [21]. Dilute salt solutions such as $\mathrm{Ca}\left(\mathrm{NO}_{3}\right)_{2}$ are useful extractants to estimate $\mathrm{Cd}$ and Zn phyto-availability [21]. Therefore, single extractions were used to assess $\mathrm{Zn}$ extractable in treated, untreated, and control soils. Every extraction was replicated three times and a quality assurance scheme included blank reagents in every batch. All glassware and plastic flasks were washed with $1.4 \mathrm{M}$ nitric acid, rinsed in distilled deionised water, and dried before use. $10 \mathrm{~g}$ of soil DW (air-dried, sieved $2 \mathrm{~mm}$ ) was shaked (run over run) with $0.1 \mathrm{M}$ calcium nitrate (suprapur, Merck) $(50 \mathrm{~mL})$ during $2 \mathrm{~h}$ at $20{ }^{\circ} \mathrm{C}$. Extracts were filtered through ash-free paper, acidified with $14 \mathrm{M}$ nitric acid (rectapur) $(1 \mathrm{~mL})$ to prevent metal adsorption to glassware, and kept at $4{ }^{\circ} \mathrm{C}$ until analysis. 


\subsection{Plant analysis}

Plant tissues were dried at $80{ }^{\circ} \mathrm{C}$ to constant weight, weighed, and then milled in a planetary grinder with a zirconium oxide covering (Retsch PM4). Aliquots (1 g DW) were then digested overnight in $14 \mathrm{M} \mathrm{HNO}_{3}(5 \mathrm{~mL})$ and $\mathrm{H}_{2} \mathrm{O}_{2} 30 \%$ by volume $(10 \mathrm{~mL})$, and heated at $120{ }^{\circ} \mathrm{C}$ for 2 hours [6]. The solutions were filtered through ash-free filter paper and made to $100 \mathrm{~mL}$ with distilled water. Metal concentrations were determined by either flame or graphite furnace atomic absorption spectrophotometry (Varian spectrA A20, A300 with deuterium background correction, and A400 with Zeeman effect), depending on the concentration. For either standards or samples, three absorbance measurements gave a relative standard deviation less than $\pm 2 \%$. Quality control of metal analyses was performed by analysing two certified samples (ryegrass and sea lettuce reference materials BCR 281 and 279 from the Community Bureau of Reference, Commission of the European Communities) and three blanks included in every batch. Metal contents in certified samples were recovered with less than $5 \%$ of variation.

For enzyme measurements, bean primary leaves were collected 14 days after sowing. Enzyme analysis was not performed in the roots because $\mathrm{Zn}$ is known to exert no measurable (iso)enzymatic effects at this level [32]; samples of $1 \mathrm{~g}$ fresh weight were frozen in liquid nitrogen and stored at $-80{ }^{\circ} \mathrm{C}$. Material was homogenised with an icecooled mortar and pestle in $5 \mathrm{~mL}$ of $0.1 \mathrm{M}$ Tris$\mathrm{HCl}$ buffer $\mathrm{pH} 7.8$, containing $1 \mathrm{mM}$ dithiothreitol and $1 \mathrm{mM}$ EDTA. The homogenate was squeezed through a nylon mesh and centrifuged at $12000 \mathrm{~g}$ and $4{ }^{\circ} \mathrm{C}$ for $10 \mathrm{~min}$. The supernatant was collected, and on this crude extract, the capacity of the following enzymes was measured spectrophotometrically with a Varian Cary 1E [33]: (gaïacol) peroxidase (GPX; E.C.: 1.11.1.7), malic enzyme (ME; E.C.: 1.1.1.40), glucose-6-phosphate dehydrogenase (G-6-PDH; E.C.: 1.1.1.49), glutamate dehydrogenase (GDH; E.C.: 1.4.4.2) and isocitrate dehydrogenase (ICDH; E.C.: 1.1.1.42). The enzyme activity was expressed in $\mathrm{mU}$ per $\mathrm{mg}$ soluble protein and per $\mathrm{g}$ FW. Soluble protein content in leaf extracts was determined using the Bio-Rad protein assay with serum bovine albumin as standard [7].

\subsection{Statistical analysis}

Datasets for shoot yields, and metal concentrations in plants and soil extracts were analysed using a one-way ANOVA (STAT.ITCF 4.0); within a column or a bargraph, mean values followed by the same letter are not significantly different at the $5 \%$ level (Newman-Keuls test).

\section{Results and discussion}

The contaminated soil AMB100 contains $1074 \mathrm{mg} \mathrm{Zn} \cdot \mathrm{kg}^{-1} \mathrm{DW}$ as compared to an initial value of $19 \mathrm{mg} \mathrm{Zn} \cdot \mathrm{kg}^{-1} \mathrm{DW}$ in the AMB0 soil (Tab. I). For the purpose of comparison, median and maximum $\mathrm{Zn}$ concentrations in French sandy soil layers are $17 \mathrm{mg}$ and $34 \mathrm{mg} \cdot \mathrm{kg}^{-1}$ soil DW [5].

\subsection{Soil $\mathrm{Zn}$ extracted by $0.1 \mathrm{M} \mathrm{Ca}\left(\mathrm{NO}_{3}\right)_{2}$}

Among soil samples, extractable $\mathrm{Zn}$ was a minimum for $\mathrm{AMB} 0$ and maximum for $\mathrm{AMB} 100$ (Tab. II). In the AMB100 and AMB0 soils, it represents $2.5 \%$ and $7.4 \%$ of total $\mathrm{Zn}$ content. Metal availability in soil is often characterised by a distribution coefficient $\mathrm{Kd}$, between the solid phase and the solution at equilibrium [3]. For all soil treatments, the $\mathrm{Kd}_{\mathrm{Zn}}$ value was here calculated by dividing total $\mathrm{Zn}$ content in soil $\left(\mathrm{mg} \cdot \mathrm{kg}^{-1}\right)$ by $\mathrm{Zn}$ concentration in $0.1 \mathrm{M} \mathrm{Ca}\left(\mathrm{NO}_{3}\right)_{2}$ extract $\left(\mathrm{mg} \cdot \mathrm{L}^{-1}\right)$. High values of $\mathrm{Kd}$ indicate high $\mathrm{Zn}$ retention by the solid phase through sorption reactions and low availability for plant uptake. $\mathrm{Kd}_{\mathrm{Zn}}$ values varied by a factor 25 and ranged from 67.4 to $1724 \mathrm{~L} \cdot \mathrm{kg}^{-1}$ (Fig. 1). Minimum and maximum values were found for control and beringite-treated soils, respectively. $\mathrm{Kd}_{\mathrm{Zn}}$ value in AMB100 soil was three fold that in AMB0 soil. Despite a higher value for $\mathrm{Zn}$ extracted, $\mathrm{Zn}$ retention in AMB100 soil is relatively larger than in AMB0 soil because $\mathrm{Zn}$ in AMB 100 is predominantly bound at lattice 
Table II. Extractable $\mathrm{Zn}^{\dagger}$, soil $\mathrm{pH}$, and cation exchange capacity (C.E.C.) in the control and the Zn-contaminated soils with and without amendments.

\begin{tabular}{|c|c|c|c|c|}
\hline $\begin{array}{l}\text { Soil } \\
\text { treatment }\end{array}$ & $\begin{array}{l}\text { Extractable } \\
\quad \mathrm{Zn} \\
\mathrm{mg} \cdot \mathrm{kg}^{-1} \mathrm{~s}\end{array}$ & $\begin{array}{l}\text { Soil pH } \\
\text { (water) } \\
\text { oil DW }\end{array}$ & $\begin{array}{l}\text { C.E.C. } \\
\text { Metson } \\
\mathrm{cmol}^{\circ} \mathrm{kg}^{-}\end{array}$ & $\begin{array}{l}\text { C.E.C. } \\
\text { Cobalti- } \\
\text { hexammine } \\
-1 \text { soil DW }\end{array}$ \\
\hline \multicolumn{5}{|c|}{ Control soil } \\
\hline \multicolumn{5}{|c|}{ Zn-contaminated soil (AMB100) } \\
\hline BER & 3.1 & 6.9 & 8.3 & 10.2 \\
\hline BIRN & 4.6 & 6.3 & 10.2 & 9.7 \\
\hline TBS & 11.1 & 6.2 & 8.5 & 9.6 \\
\hline SSTBS & 8.6 & 6.6 & 10.0 & 9.1 \\
\hline $\mathrm{SS}$ & 15.3 & 6.4 & 9.9 & 9.3 \\
\hline MAGN & 21.8 & 5.8 & 8.5 & 7.9 \\
\hline MAGH & 25.7 & 5.6 & 8.6 & 9.3 \\
\hline HEM & 19.7 & 6.1 & 10.2 & 10.9 \\
\hline $\mathrm{HMOCaO}$ & 14.6 & 5.9 & 9.1 & 9.5 \\
\hline Untreated & 26.7 & 5.8 & 9.4 & 8.4 \\
\hline
\end{tabular}

$\dagger 0.1 \mathrm{M} \mathrm{Ca}\left(\mathrm{NO}_{3}\right)_{2}$

vacancy sites of the phyllomanganate chalcophanite $\left(\mathrm{ZnMn}_{3} \mathrm{O}_{7} \cdot 3 \mathrm{H}_{2} \mathrm{O}\right)$ [23]. This oxide originates from the large Mn concentration in the sludge applied. Its structure presents similarities with birnessite. All soil treatments except maghemite led to a significant increase in $\mathrm{Kd}_{\mathrm{Zn}}$ (Fig. 1). The amendment nature and changes in soil $\mathrm{pH}$ caused $\mathrm{Kd}_{\mathrm{Zn}}$ changes. However, other parameters such as the concentration ratio between the sorbed element and the ligands, ionic strength, and the presence of competing ions may contribute. For the AMB100 soil, beringite and birnessite treatments by far delivered the most pronounced increases in the $\mathrm{Zn}$ distribution coefficient, 8.6 and 5.4 fold respectively as compared with the untreated soil. However, the beringite amount added to the $\mathrm{Zn}$-contaminated soil was 5 times higher than that of birnessite. Thus, birnessite appeared to decrease extractable $\mathrm{Zn}$ to the highest extent. Its large sorption capacity results from its chemical and structural properties [29]. The replacement of $\mathrm{Mn}^{\mathrm{IV}}$ by $\mathrm{Mn}^{\mathrm{III}}$ and the presence of layer vacancies $(\square)$ in the structure create a deficit of positive charges balanced predominantly by interlayer $\mathrm{Na}$. The exchange capaci-

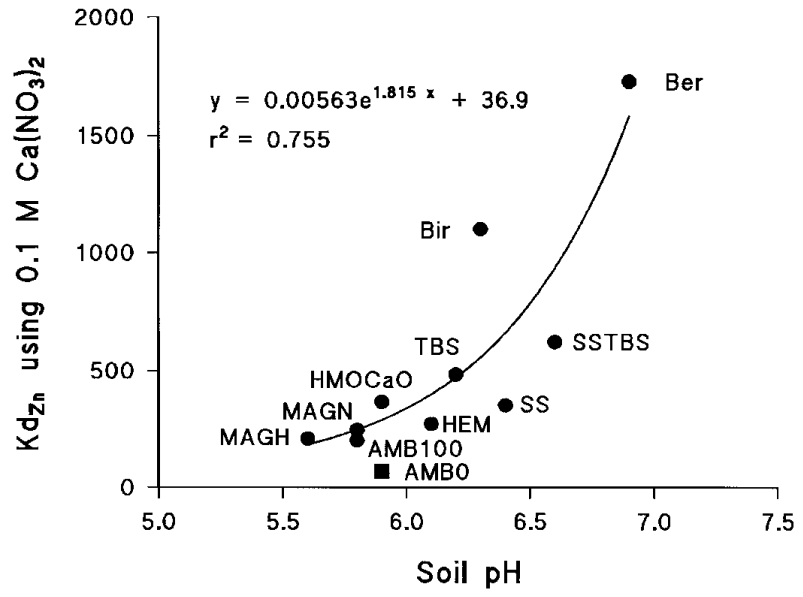

Figure 1. Changes in $\mathrm{Kd}_{\mathrm{Zn}}(0.1 \mathrm{M}$ calcium nitrate extractable$\mathrm{Zn}, \mathrm{mg} \cdot \mathrm{L}^{-1}$ vs. total $\mathrm{Zn}$ content in soil, $\mathrm{mg} \cdot \mathrm{kg}^{-1}$ ) in relation to soil $\mathrm{pH}$ (water) as a result of the addition of amendments to a coarse sandy soil contaminated by sludge-borne $\mathrm{Zn}$.

ty of this material is as high as $300 \mathrm{cmol} \cdot \mathrm{kg}^{-1}$ [36], three times larger than that of typical montmorillonite. In comparison, the CEC of beringite is equal to $20 \mathrm{cmol} \cdot \mathrm{kg}^{-1}$ [27]. When equilibrated in neutral to acidic conditions, Na-birnessite can sorb large metal amounts. Metals form three Me-O-Mn bonds at the birnessite surface [23, 24, 29]. This sorption mechanism accounts for the high binding affinity and low reversibility of metal sorption experiments [23]. Our data confirmed beringite at the $50 \mathrm{~g} \cdot \mathrm{kg}^{-1}$ rate as an efficient amendment for rendering $\mathrm{Zn}$ less mobile [33, 34]. Its metal immobilising capacity is supposed to be based on the combination of 3 mechanisms [27, 35]: (i) metals rapidly (hours) adsorbed onto highly accessible sites on the surface of the modified clay and the original soil components freed due to a liming effect; (ii) a slower type (days) of sorption occured such as coprecipitation associated with $\mathrm{Al}, \mathrm{Fe}$, and Mn oxides; and (iii) on the longer term (years) minerals such as metal silicates can form and metals diffuse across the mineral surface.

Four other amendments caused a 2.4 to 3 fold increase in $\mathrm{Kd}_{\mathrm{Zn}}$ when they were applied to AMB 100: SS, HMOCaO, TBS, and SSTBS. Mixed together, SS and TBS were more efficient to decrease extractable $\mathrm{Zn}$ than when used separately. SS mainly contains $\alpha-\mathrm{Fe}(98 \%)$ but also native $\mathrm{Mn}$ 
as an impurity (e.g. $7710 \mathrm{mg} \cdot \mathrm{kg}^{-1} \mathrm{DW}$ ) [28]. X-ray diffraction and Extended X-ray Absorption Fine Structure (EXAFS) spectroscopy show that native iron was oxidised in this sandy soil to lepidocrocite $(\gamma \mathrm{FeOOH})$, magnetite and maghemite whereas $\mathrm{Mn}$ transformed to a birnessite-like phyllomanganate compound [23, 28]. First, the addition of crystallised iron oxides such as hematite, maghemite and magnetite in soil proved unsuccessful for decreasing $\mathrm{Zn}$ extracted. Second, Mn content in the shot is only $8 \mathrm{~g} \cdot \mathrm{kg}^{-1}$ and not all of the steel would oxidise after the one month reaction period. Using $\mathrm{X}$-ray diffraction, it has been reported that some $\alpha$-Fe is still present in oxidised shots recovered with a magnet from a sandy soil [28]. Thus, reduction in $\mathrm{Zn}$ brought about by the addition of steel shots is probably due to the specific surface area of a layer of fresh iron oxides forming on either the shot or soil particles. These in situ newly-formed oxides would have a larger surface area than the bulk oxide minerals added. Newly-formed Mn oxides in SS-treated soils may also enhance $\mathrm{Zn}$ inactivation as in the HMO-and birnessite treated soils, but further investigation is needed to quantify their contribution compared with iron oxides. Alkaline compounds such as TBS increased soil $\mathrm{pH}$ and the contribution of $\mathrm{CaO}$ limited the wellknown acidifying effect of HMO (Fig. 1). In the 6.0-6.5 $\mathrm{pH}$ range, $\mathrm{pH}$ increase can likely enhance $\mathrm{Zn}$ sorption on the particles of $\mathrm{Fe}$ and Mn-oxides initially present in the contaminated soil, or newly formed following the addition of SS, or directly added as amendments (HMO).

Soil $\mathrm{pH}$ was modified following the addition of several amendments into the zinc-contaminated soil (Fig. 1). A relationship was found between soil $\mathrm{pH}$ and $\mathrm{Kd}_{\mathrm{Zn}}$ among data related to AMB100. However, treatments such as MAGN and $\mathrm{HMOCaO}$ increased $\mathrm{KdZn}$ although soil $\mathrm{pH}$ did not vary significantly. Other mechanisms than surface complexation and acid-base reaction may thus be hypothesised. The CEC of soil samples was determined either in a buffered ammonium acetate solution at $\mathrm{pH} 7$ (Metson method) or by respecting soil pH (cobaltihexammine method) (Tab. II). When soil $\mathrm{pH}$ was not buffered, an increase in CEC was found following soil treatment, except with magnetite. This compound had an opposite effect. Soil $\mathrm{pH}$ was the highest correlated variable with $\mathrm{Kd}_{\mathrm{Zn}}(\mathrm{r}=0.80, p<0.01)$. A weaker correlation $(\mathrm{r}=0.44, p<0.01)$ was found for the CEC (cobaltihexammine).

\subsection{Plant yield}

Plant yield could be used as an index of amelioration success. However decrease in yield is not always a proof for metal phytotoxicity. Bean did not germinate when sown in the untreated and limed $\left(0.5 \mathrm{~g} \cdot \mathrm{kg}^{-1}\right)$ AMB100 soils (Tab. III). Every other soil treatment enhanced the dry-matter yield of bean plants. Moderate chlorosis was observed on the primary leaves of seedlings cultivated on AMB100 added with either HMOCaO or HEM. Relative to the control treatment, beringite application resulted in an increase in the yield of bean roots. The smallest yield of bean shoots was associated with the $\mathrm{HMOCaO}$ addition. Nodules of Rhizobium were only found on the roots of plants grown in the control soil.

Table III. Dry-matter yields (g.plant $\left.{ }^{-1}, \mathrm{DW}\right)$ and shoot length $(\mathrm{cm})$ of dwarf beans.

\begin{tabular}{lccc}
\hline Soil treatment & $\begin{array}{c}\text { Shoot } \\
\text { length }\end{array}$ & $\begin{array}{c}\text { Shoot } \\
\text { yield }\end{array}$ & $\begin{array}{c}\text { Root } \\
\text { yield }\end{array}$ \\
\hline $\begin{array}{l}\text { Control soil } \\
\text { (AMB0) }\end{array}$ & $9.3 \mathrm{a}$ & $1.4 \mathrm{~b}$ & $0.51 \mathrm{~b}$ \\
\multicolumn{4}{l}{ Zn-contaminated soil } \\
(AMB100) & & \\
Untreated & 0 & 0 & 0 \\
TBS & $8.3 \mathrm{a}$ & $1.7 \mathrm{a}$ & $0.47 \mathrm{~b}$ \\
SS & $7.9 \mathrm{a}$ & $1.8 \mathrm{a}$ & $0.53 \mathrm{~b}$ \\
SSTBS & $8.8 \mathrm{a}$ & $2.0 \mathrm{a}$ & $0.53 \mathrm{~b}$ \\
MAGN & $8.9 \mathrm{a}$ & $1.8 \mathrm{a}$ & $0.52 \mathrm{~b}$ \\
MAGH & $9.1 \mathrm{a}$ & $1.9 \mathrm{a}$ & $0.61 \mathrm{~b}$ \\
HEM & $9.4 \mathrm{a}$ & $2.1 \mathrm{a}$ & $0.54 \mathrm{~b}$ \\
BER & $9.1 \mathrm{a}$ & $2.1 \mathrm{a}$ & $0.73 \mathrm{a}$ \\
BIRN & $8.6 \mathrm{a}$ & $1.7 \mathrm{a}$ & $0.59 \mathrm{~b}$ \\
HMOCaO & $7.8 \mathrm{a}$ & $1.4 \mathrm{~b}$ & $0.55 \mathrm{~b}$ \\
CaO & 0 & 0 & 0
\end{tabular}

Mean values with different letters within a column are significantly different $(p<0.05)$. 
Table IV. Ryegrass shoot yield $\left(\mathrm{g} \cdot \mathrm{pot}^{-1}, \mathrm{DW}\right)$.

\begin{tabular}{lccc}
\hline Treatment & Cut \#1 & Cut \#2 & Cut \#3 \\
\hline $\begin{array}{l}\text { Control soil } \\
\text { AMB0 }\end{array}$ & $2.07 \mathrm{~b}$ & $1.75 \mathrm{~d}$ & $2.47 \mathrm{~b}$ \\
& & & \\
Zn-contaminated soil & (AMB100) & & \\
MAGN & $2.29 \mathrm{ab}$ & $2.24 \mathrm{bc}$ & $3.58 \mathrm{a}$ \\
HEM & $2.24 \mathrm{ab}$ & $2.16 \mathrm{c}$ & $3.37 \mathrm{a}$ \\
BER & $2.51 \mathrm{a}$ & $2.43 \mathrm{abc}$ & $3.54 \mathrm{a}$ \\
SS & $2.37 \mathrm{ab}$ & $2.64 \mathrm{ab}$ & $3.86 \mathrm{a}$ \\
SSTBS & $2.18 \mathrm{ab}$ & $2.39 \mathrm{abc}$ & $3.51 \mathrm{a}$ \\
TBS & $2.55 \mathrm{a}$ & $2.44 \mathrm{abc}$ & $4.07 \mathrm{a}$ \\
BIRN & $2.39 \mathrm{ab}$ & $2.13 \mathrm{c}$ & $3.83 \mathrm{a}$ \\
HMOCaO & $2.32 \mathrm{ab}$ & $2.31 \mathrm{abc}$ & $3.45 \mathrm{a}$ \\
MAGH & $2.25 \mathrm{ab}$ & $2.45 \mathrm{abc}$ & $3.39 \mathrm{a}$ \\
Untreated & $2.18 \mathrm{ab}$ & $2.74 \mathrm{a}$ & $3.72 \mathrm{a}$ \\
\hline
\end{tabular}

Mean values with different letters within a column are significantly different $(p<0.05)$.

In contrast to bean, ryegrass growth was not affected by the $\mathrm{Zn}$ excess in untreated AMB100 (Tab. IV) and the smallest yield was even obtained in the control soil for every harvest. In the untreated and treated $\mathrm{Zn}$-contaminated soils, nutrients are likely released as sludge progressively decays in the soil. The ryegrass growth for AMB 100 was increased in cut \#2 and cut \#3. At the first and third harvests, changes in ryegrass yield among treatments were not significant. But in cut \#2, magnetite, hematite and birnessite were less effective than the other materials.

\subsection{Zn availability to plants}

For the primary leaves and shoots of bean, the smallest $\mathrm{Zn}$ concentrations were found for AMB0 and BER-treated soils (Tab. V). The largest ones were observed upon addition of iron oxides such as hematite, magnetite, and maghemite. Relative to AMB $0, \mathrm{Zn}$ concentration in primary leaves increased about four-fold when plants were grown on these treated-soils. In addition to beringite, several amendments, i.e. SS, HMOCaO, TBS, SSTBS, and BIRN, proved to be effective in mitigating $\mathrm{Zn}$ accumulation in aerial plant parts. Larger $\mathrm{Zn}$ concentrations were determined in roots than in aerial tissues. The smallest $\mathrm{Zn}$ concentrations in roots were measured for the control soil and the beringite addition. Both birnessite and beringite reduced $\mathrm{Zn}$ uptake. But relative to the application rate, birnessite was the most effective to reduce shoot- $\mathrm{Zn}$ because it was only applied at $10 \mathrm{~g} \cdot \mathrm{kg}^{-1}$ whereas BER was used at $50 \mathrm{~g} \cdot \mathrm{kg}^{-1}$. Beringite applied at $10 \mathrm{~g} \cdot \mathrm{kg}^{-1}$ was found uneffective in limiting $\mathrm{Zn}$ toxicity for dwarf beans in a Zn-contaminated soil [35].

Table V. Zn and Mn concentrations (mg.kg-1 ${ }^{-1}$ DW) in plant parts of 14-day-old Phaseolus vulgaris seedlings.

\begin{tabular}{|c|c|c|c|c|c|}
\hline \multirow[t]{2}{*}{ Soil treatment } & \multicolumn{2}{|c|}{ Primary leaf } & \multirow{2}{*}{$\begin{array}{c}\text { Shoot } \\
\mathrm{Zn}\end{array}$} & \multirow{2}{*}{$\begin{array}{c}\text { Roots } \\
\mathrm{Zn}\end{array}$} & \multirow{2}{*}{$\frac{\text { Shoot/roots }}{\mathrm{Zn}}$} \\
\hline & $\mathrm{Zn}$ & $\mathrm{Mn}$ & & & \\
\hline Control soil (AMB0) & $44 \mathrm{e}$ & $58 \mathrm{~d}$ & $56 \mathrm{~d}$ & $430 \mathrm{~g}$ & 0.13 \\
\hline \multicolumn{6}{|l|}{ Zn-contaminated soil (AMB100) } \\
\hline Untreated & no plant & & no plant & no plant & \\
\hline TBS & $94 \mathrm{~cd}$ & $80 \mathrm{c}$ & $90 \mathrm{c}$ & $884 \mathrm{e}$ & 0.10 \\
\hline SS & $86 \mathrm{~cd}$ & $93 \mathrm{c}$ & $104 \mathrm{~b}$ & $1152 \mathrm{~cd}$ & 0.09 \\
\hline SSTBS & $98 \mathrm{~cd}$ & $87 \mathrm{c}$ & $93 \mathrm{bc}$ & $943 \mathrm{e}$ & 0.10 \\
\hline MAGN & $171 \mathrm{a}$ & $428 \mathrm{a}$ & $143 \mathrm{a}$ & 1703 a & 0.08 \\
\hline MAGH & $143 \mathrm{~b}$ & $269 \mathrm{~b}$ & $139 \mathrm{ab}$ & $1473 \mathrm{~b}$ & 0.09 \\
\hline HEM & $134 \mathrm{~b}$ & $90 \mathrm{c}$ & $138 \mathrm{ab}$ & $1297 \mathrm{c}$ & 0.11 \\
\hline BER & $69 \mathrm{de}$ & $83 \mathrm{c}$ & $62 \mathrm{~d}$ & $580 \mathrm{fg}$ & 0.11 \\
\hline BIRN & $87 \mathrm{~cd}$ & $299 \mathrm{~b}$ & $82 \mathrm{c}$ & $695 \mathrm{f}$ & 0.12 \\
\hline HMOCaO & $112 b c$ & $464 \mathrm{a}$ & $96 \mathrm{c}$ & $1037 \mathrm{de}$ & 0.09 \\
\hline $\mathrm{CaO}$ & no plant & & no plant & no plant & \\
\hline
\end{tabular}

Mean values with different letters within a column are significantly different $(p<0.05)$. 


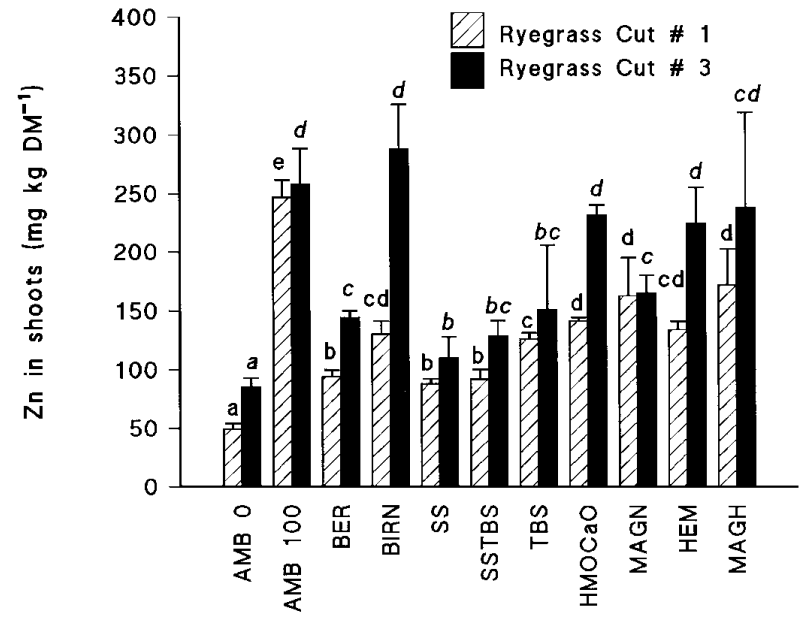

Figure 2. $\mathrm{Zn}$ concentration in ryegrass shoots harvested at 3 months (cut \#1) and 5 months (cut \#3) following a single application of amendment on a coarse sandy soil contaminated by sludge-borne $\mathrm{Zn}$. For each cut, mean values with the same letter are not significantly different at the 5\% level (NewmanKeuls test).

The sustainability of the $\mathrm{Zn}$-immobilising effect following a single application of amendment was tested using subsequent ryegrass cuts from 2 to 5 months after the soil treatment. Zn concentrations in ryegrass shoots collected at the 1 st and 3rd harvests are shown in Figure 2. Critical value (at a 20\% reduction level) for $\mathrm{Zn}$ in ryegrass shoot was between $370-560 \mathrm{mg} \cdot \mathrm{kg} \mathrm{DW}^{-1}$ at soil $\mathrm{pH} 6.7$ [22]. $\mathrm{Zn}$ concentration in the ryegrass shoot collected in untreated AMB100 was four to five times larger compared to AMB0 depending on the number of harvests. At the first cut, a decrease in shoot $\mathrm{Zn}$ concentrations was observed for all treated soils (Fig. 2). However, the most effective amendments for mitigating $\mathrm{Zn}$ uptake in shoots were SS, SSTBS and beringite; on the other hand, iron oxides (maghemite, magnetite, and hematite) as well as Mn-oxides (birnessite, $\mathrm{HMOCaO}$ ) were the least effective treatments. The immobilising effect was further examined at the 3rd harvest (Fig. 2). Zn availability to ryegrass cultivated in AMB 0 and AMB100 did not change relative to the 1st harvest. SS and SSTBS treatments were again among the most effective soil amendments leading to a decrease in $\mathrm{Zn}$ concentration in shoots. Beringite, basic slags and magnetite reduced also $\mathrm{Zn}$ accumulation in the ryegrass shoots. The effect of birnessite addition on $\mathrm{Zn}$ availability was not persistent and $\mathrm{Zn}$ concentration in ryegrass shoots was similar for both the untreated and birnessite-treated soils. Zn sorption on Mn-oxides may have been affected by the roots potted in a relatively small volume. Roots of some plant species are able to release Mn from Mn-oxides in the rhizosphere [30], and inorganic elements may be recycled from disintegrated roots as well. Mn concentration was determined in ryegrass shoots harvested at the 1 st and 3rd harvests (Fig. 3). Indeed, Mn concentrations were larger at the 3rd harvest than at the 1st one for all treatments investigated, and a very high Mn concentration was noticed in the $\mathrm{HMOCaO}$ treatment. The highest relative increase in Mn concentration (4 times) was found for the birnessite-treated soil. The subsequent ryegrass harvests preclude the birnessite effectiveness in this pot study but this must be tested using a larger soil volume and a longer growth period. Rhizosphere process and roots containment may also affect Zn sorption by SS, SSTBS, and BER and must be studied as well. At a zinc-smelter contaminated field site, the $\mathrm{Zn}$ water-extracted fraction was up to 70 times smaller in the beringitetreated soil 5 years after application of the soil amendment [35].

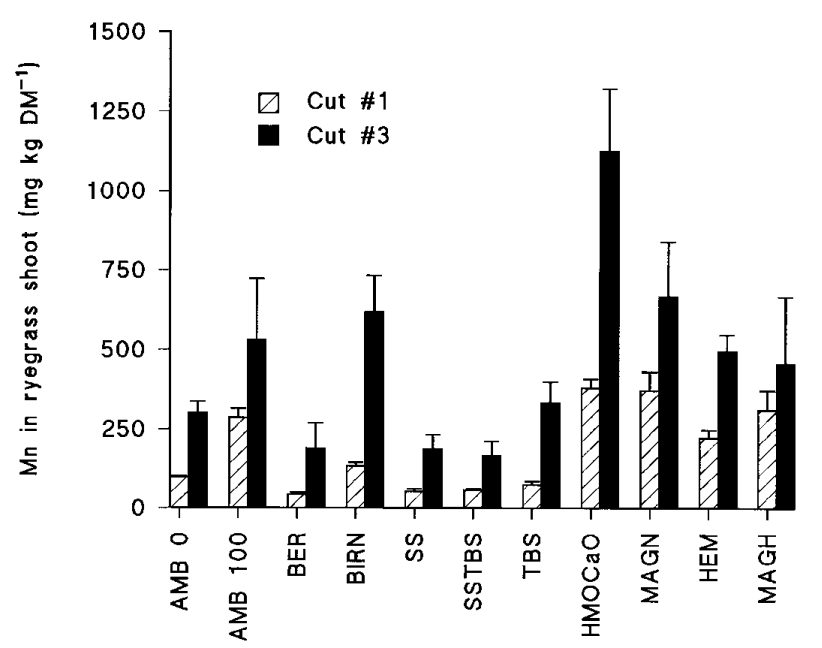

Figure 3. Mn concentration in ryegrass shoots harvested at 3 months (cut \#1) and 5 months (cut \#3) following a single application of amendment on a coarse sandy soil contaminated by sludge-borne $\mathrm{Zn}$. For each cut, mean values with the same letter are not significantly different at the $5 \%$ level (NewmanKeuls test). 


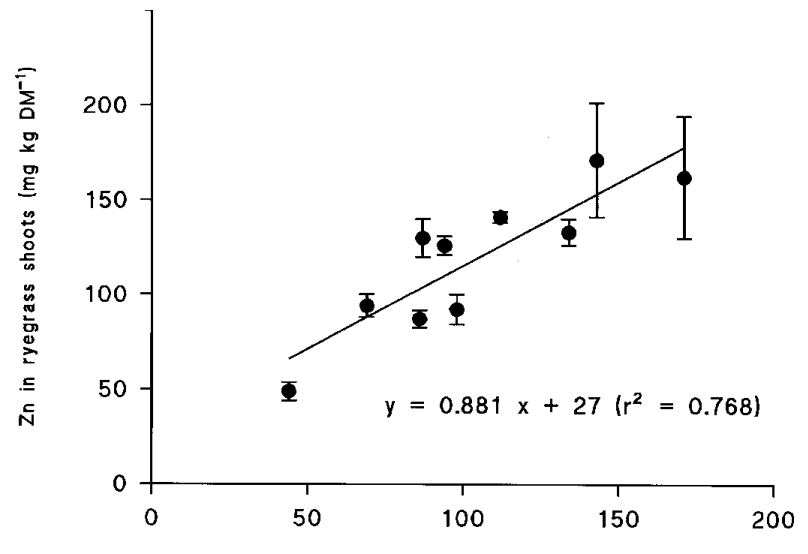

Figure 4. Relationship between $\mathrm{Zn}$ concentrations in dwarf bean and ryegrass (cut \#1) shoots for plants grown on the zinccontaminated soil, untreated and treated by the addition of amendments.

Zn concentrations in the primary leaves of dwarf bean and ryegrass shoots (1st harvest) are linearly related (Fig. 4). $\mathrm{Zn}$ in ryegrass shoots harvested on the $\mathrm{Zn}$-contaminated soil was $246 \pm 15 \mathrm{mg} \mathrm{Zn} \cdot \mathrm{kg}^{-1}$ DM. Accordingly, the relationship allowed for estimates of $\mathrm{Zn}$ accumulation in primary leaves of dwarf bean as large as $249 \mathrm{mg} \mathrm{Zn} \cdot \mathrm{kg}^{-1} \mathrm{DM}$, thus exceeding the critical value in this bean part, i.e. $227 \mathrm{mg} \mathrm{Zn} \cdot \mathrm{kg}^{-1} \mathrm{DM}[32]$. This likely explains why bean plants did not grow in the untreated AMB100 soil.

\subsection{Relationship between soil $\mathrm{Zn}$ extracted and $\mathrm{Zn}$ in aerial plant parts}

Decrease in extractable $\mathrm{Zn}$ in soil following the application of amendments (i.e. BER, BIRN, SSTBS, TBS, HMOCaO) was mirrored by a decrease in $\mathrm{Zn}$ accumulated in both bean shoot and primary leaf (Figs. 5a and 5b). For the shoots, the combination of two Michaelis-Menten equations was found to be the best curve fit, with in a first plateau at $95 \mathrm{mg} \mathrm{Zn} \cdot \mathrm{kg} \mathrm{DM}^{-1}$ corresponding to $15 \mathrm{mg} \mathrm{Zn}$ extracted by $0.1 \mathrm{M} \mathrm{Ca}\left(\mathrm{NO}_{3}\right)_{2}$ per $\mathrm{kg}$ soil DW. This may reflect subsequent mechanisms in bean as $\mathrm{Zn}$ exposure increased. $\mathrm{Zn}$ in ryegrass shoots at the first harvest and extractable $\mathrm{Zn}$ in soil are also related (Fig. 5c).
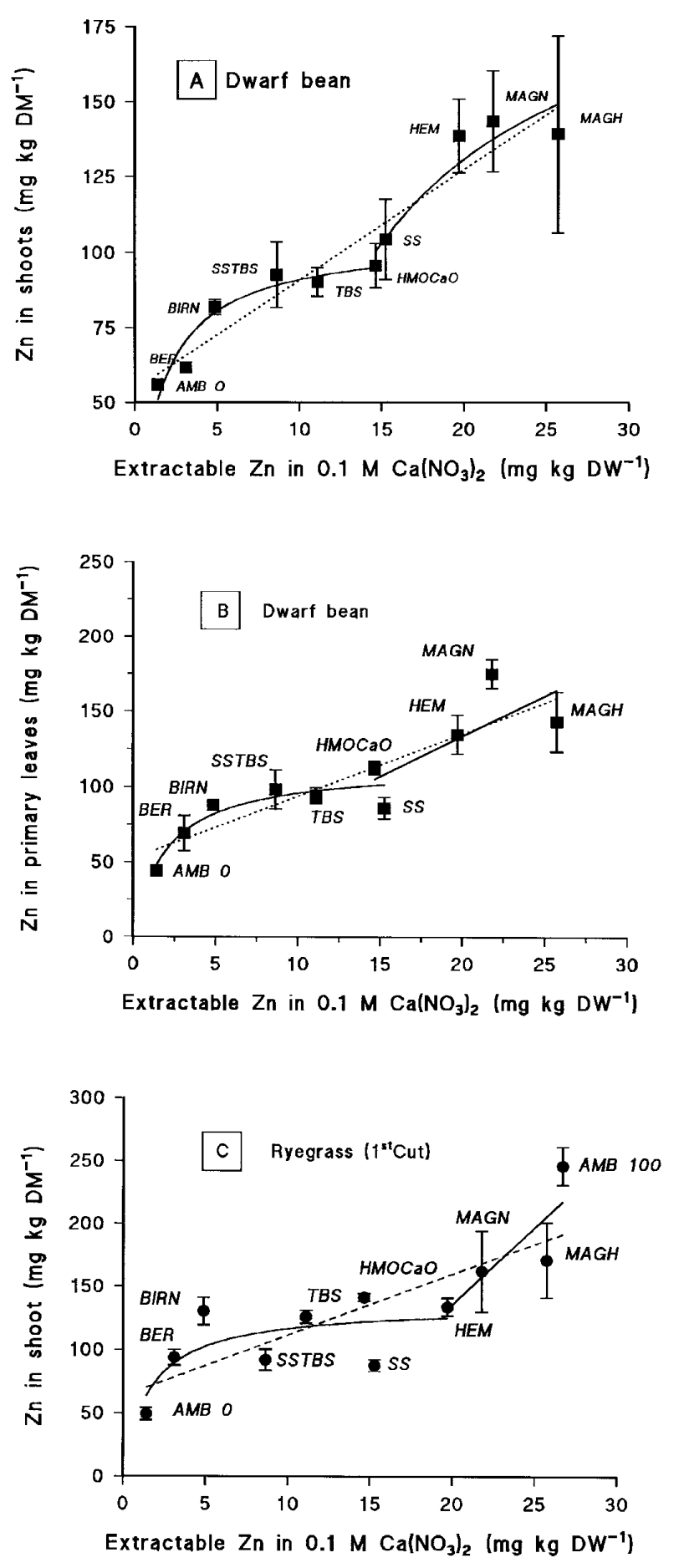

Figure 5. Relationship between $\mathrm{Kd}_{\mathrm{Zn}}(0.1 \mathrm{M}$ calcium nitrate extractable-Zn vs. total $\mathrm{Zn}$ content in soil) and $\mathrm{Zn}$ concentration in the shoot (a) and primary leaves (b) of dwarf bean, and in ryegrass shoots (c). 


\subsection{Biological evaluation of the soil phytotoxicity}

Metals assimilated through the roots interfere with metabolic processes. Early biochemical responses to metals, e.g. changes in enzyme activities, can be detected before the appearance of any visible symptom of phytotoxicity, and used as diagnostic criteria to quantify soil phytotoxicity $[32,33]$. The induction of GPX, ME, ICDH, G6PDH, and GDH in the primary leaves of dwarf bean is considered to limit the detrimental effect of $\mathrm{Zn}$ on metabolic processes [31]. Therefore, these enzyme capacities and the soluble protein content were measured on the bean primary leaves. Most significant effects between the soil treatments were found for all these parameters when data were expressed per g fresh weight (FW) (Fig. 6). Soluble protein content was smallest in the HEM, BER, and SSTBS treatments (Fig. 6a); their values were similar to the control ones. Largest protein content was found for birnessite and $\mathrm{HMOCaO}$.

Peroxidase induction is thought to be related to defense against oxidative stress, especially for scavenging the formation of hydrogen and organic peroxides, and is correlated to $\mathrm{Zn}, \mathrm{Cd}$ and $\mathrm{Cu}$ assimilated by dwarf bean [32]. For control soils, typical values for GPX activity in primary bean leaf range between 900-2 $000 \mathrm{mU} \cdot \mathrm{g} \mathrm{FW}^{-1}$ depending on season $[26,33,34]$. The value for AMB0 was within this range (Fig. 6b). Relative to the control soil, a significant increase in GPX activity occurred when plants were grown on the $\mathrm{Zn}$-contaminated soil treated with $\mathrm{HMOCaO}$, SSTBS, SS, and MAGN. GPX activity was restored to the control value by the following amendments: beringite, birnessite, and TBS. Induction in GPX activity was greatest for the $\mathrm{HMOCaO}$ treatment even though its leaf $\mathrm{Zn}$ concentration was lower than in MAGN (Tab. V), and an additional process was hypothesised. Leaf analysis showed a large increase in Mn concentration upon hydrous Mn oxides or magnetite addition to the soil (Tab. V), and Mn accumulation is supposed to induce GPX activity in bean [25]. Hydrous Mn oxide was synthesised at low $\mathrm{pH}$ and therefore soluble. $\mathrm{CaO}$ application was likely unsuccessful in inhibiting the HMO dissolution in soil.
In primary bean leaf grown on control soils, typical values for the G6PDH, ICDH and ME activities are 300-400 $\mathrm{mU}, 400-700 \mathrm{mU}$, and $600-700 \mathrm{mU}$ per $\mathrm{g} \mathrm{FW}^{-1}$, respectively $[26,33,34]$. These enzyme activities increase as a result of $\mathrm{Zn}$ accumulation in these leaves [26, 31-33]. Significant changes in ICDH, G6PDH, and ME activities were measured among the treatments (Figs. 6c, 6d and 6e). For G6PDH, the addition of BER, BIRN, and SS to the zinc-contaminated soil resulted in an enzyme activity similar to the control value. In contrast, the addition of iron oxides such as maghemite, hematite and magnetite showed the largest $\mathrm{Zn}$ concentration in the primary leaves and thus G6PDH activity was markedly high. Beringite, and birnessite led to a decrease in both ICDH and ME activities, reaching typical values for control soils. This reflects the decrease in $\mathrm{Zn}$ concentration in primary leaf due to these treatments. Relationships between $\mathrm{Zn}$ concentration in the primary leaf and either ICDH, ME or G6PDH activity were evidenced (Fig. 7). The higher capacity of these enzymes which catalyse NAD $(\mathrm{P})+$ reducing reactions has been suggested to compensate for a possible shortage of reducing capacity in the cell because $\mathrm{Zn}$ inhibits chloroplast NADPH production [31]. GDH activity in the primary leaves of dwarf bean grown on control soils was 300-400 mU per kg FW. A significant increase in $\mathrm{GDH}$ activity was found only for the $\mathrm{HMOCaO}$ treatment (Fig. 6f). It was also reported for dwarf bean following HMO addition in a limed-silty soil [25], and may be related to increase in leaf $\mathrm{Mn}$ concentration. However, GDH induction was not found for MAGN even though the leaf Mn concentration was similar. Critical value for Mn toxicity in dwarf bean leaf, i.e. $1000 \mathrm{mg} \cdot \mathrm{kg}^{-1} \mathrm{DM}$ [22], is not exceeded (Tab. V).

Even though changes in shoot length and drymatter yield in dwarf bean were unsignificant among soil treatments except for limed and untreated soils (Tab. III), metabolic responses in the primary leaf allow two treatment groups to be distinguished. Birnessite $\left(10 \mathrm{~g} \cdot \mathrm{kg}^{-1}\right)$, and beringite $\left(50 \mathrm{~g} \cdot \mathrm{kg}^{-1}\right)$ applied to the $\mathrm{Zn}$-contaminated soil clearly restored the enzyme activities in the primary leaves of 14-day-old plants to control values. This 

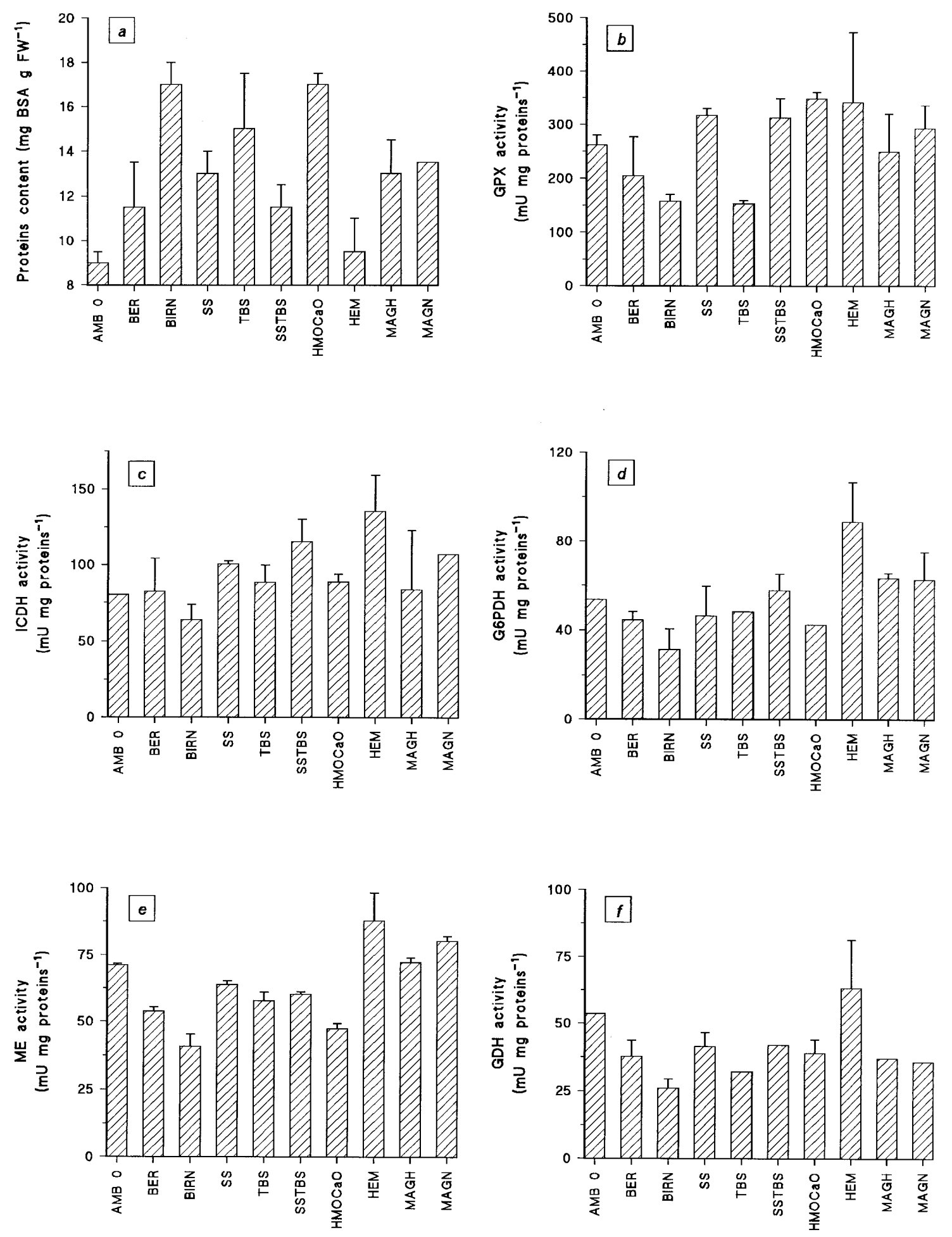

Figure 6. Soluble protein contents (a), (gaïacol)peroxidase (b), isocitrate dehydrogenase (c), glucose-6-phosphate dehydrogenase (d), malic enzyme (e), and glutamate dehydrogenase (f) activities in the primary leaf of 14-day-old Phaseolus vulgaris L. grown on the control soil, the untreated and amended $\mathrm{Zn}$-contaminated soils. 


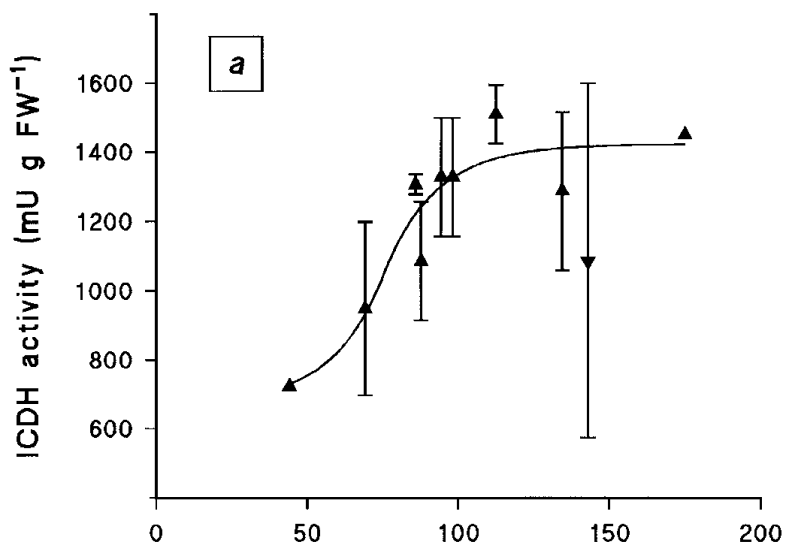

$\mathrm{Zn}$ in primary leaves ( $\mathrm{mg} \mathrm{kg} \mathrm{DM}^{-1}$ )

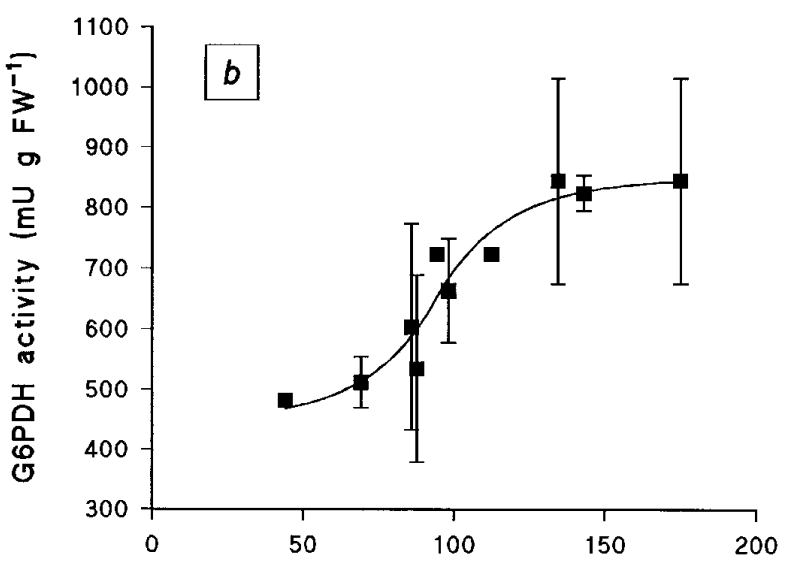

$\mathrm{Zn}$ in primary leaves $\left(\mathrm{mg} \mathrm{kg} \mathrm{DM}{ }^{-1}\right.$ )

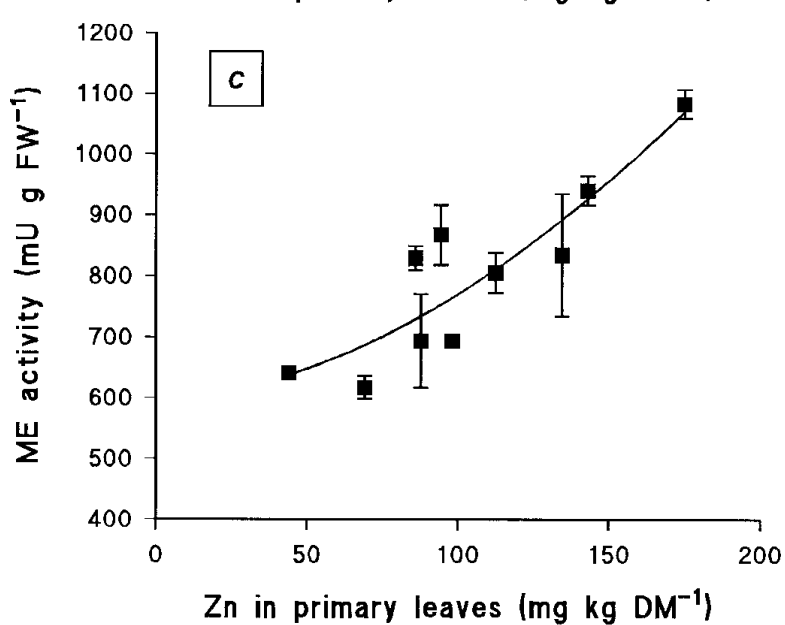

Figure 7. Changes in isocitrate dehydrogenase (a), glucose-6phosphate dehydrogenase (b), and malic enzyme (c) activities in relation to $\mathrm{Zn}$ concentration in primary leaves of 14-day-old Phaseolus vulgaris L. grown on the control soil, the untreated and amended $\mathrm{Zn}$-contaminated soils. reflected the decrease in $\mathrm{Zn}$ accumulation in primary leaves (Tab. V). Application of hematite, steel shots with and without basic slags, basic slags, maghemite, magnetite, HMO combined with lime in the zinc-contaminated soil did not suppress the metabolic stress due to $\mathrm{Zn}$ assimilated from the soil.

\section{Conclusion}

This pot experiment aimed to evaluate the amendment effect on sludge-borne $\mathrm{Zn}$ phytoavailability in a sandy soil. The range of inorganic compounds comprised iron oxides (hematite, magnetite, maghemite), manganese oxides (birnessite, hydrous Mn oxides), steel shots that oxidised in iron and manganese oxides, a modified aluminosilicates (beringite) and alkaline compounds (lime, Thomas basic slags). Based on the addition rate, the largest decrease in extractable $\mathrm{Zn}$ was found in the birnessite $\left(10 \mathrm{~g} \cdot \mathrm{kg}^{-1}\right)$-treated soils. Steel shots combined with TBS were the second promising amendment. Beringite was very efficient but with a higher addition rate $\left(50 \mathrm{~g} \cdot \mathrm{kg}^{-1}\right)$. It is suggested that an alkaline material such as beringite combined with steel shots may hold promise to immobilise $\mathrm{Zn}$ in soil. Products such as beringite, steel shots, and basic slags are even more interesting because they are commercially available in industrial quantities. Germination of dwarf bean was highly affected in the untreated and limed zinc-contaminated soils, whereas all other amendments restored and enhanced the growth of 14-day-old dwarf bean. Zn concentration in bean aerial parts was decreased and enzyme activities in primary leaves restored to the highest extent with beringite and birnessite. Amendments such as SS, SSTBS, TBS and $\mathrm{HMOCaO}$ were also efficient to limit the root exposure to $\mathrm{Zn}$ and consequently its accumulation in bean aerial parts. Similar results were found for the first cut of ryegrass shoots. Based on subsequent harvests of ryegrass, decrease in $\mathrm{Zn}$ availability as a result of either beringite, steel shots, steel shots combined with basic slags, or basic slags addition was persistent for a 5 month period. Although pot experiments cannot replace long-term field experiments, this result suggests that the effect of these 
amendments on sludge-borne $\mathrm{Zn}$ phytoavailability can be sustainable. In a field experiment at the site of a former $\mathrm{Zn}$ smelter in Belgium, the metal immobilising effect of a beringite soil treatment $\left(50 \mathrm{~g} \cdot \mathrm{kg}^{-1}\right)$ remains effective over at least a 5 year period $[34,35]$. To further test available products such as beringite and steel shots in practice, they were applied at $50 \mathrm{~g}$ and $10 \mathrm{~g} \cdot \mathrm{kg}^{-1}$ into the top layer (0 to $25 \mathrm{~cm}$ depth) of four experimental plots of a field experiment with sludged-soils at the INRA Couhins experimental farm, Bordeaux, France. The long term effect of these soil treatments is being studied with a maize monoculture. In contrast, reduction in $\mathrm{Zn}$ availability to ryegrass by birnessite was not sustainable on a 5 month period. It is recommended that further long-term field trials be performed on the addition of beringite, steel shots, basic slags and their combinations, with various soil types and anthropogenic zinc origin. Further experiments are needed at various concentrations and frequencies of soil application of birnessite before its long term efficacy can be evaluated.

Acknowledgements: The authors are grateful to Mrs S. Bussière-Fargues, Mr T. Prunet, INRA Unité d'Agronomie, Centre de Recherches BordeauxAquitaine, France and Mrs C. Put and A. Wÿgaerts, Limburgs Universitair Centrum, Department SBG, Diepenbeek, Belgium for technical assistance. This work was funded by the Ministère des Affaires Etrangères, Paris and Ministerie van de Vlaamse Gemeenschap, Brussels for scientific exchanges (Programme Tournesol 93007). The authors want to extend thanks to the European Commission, Directorate Generale XII which supports the continuation of this work within the Environment \& Climate programme, programme PHYTOREHAB, and to Magnox Pulaski Incorporated who supplied iron oxides MAGH and MAGN.

\section{References}

[1] Adriano D.C., Trace Elements in the Terrestrial Environment, Springer Verlag, New York, 1986.

[2] Alloway B., Heavy Metals in Soils, 2nd ed., Blackie Academic \& Professional, London, 1995.

[3] Anderson P.R., Christensen T.H., Distribution coefficients of $\mathrm{Cd}, \mathrm{Co}, \mathrm{Ni}$, and $\mathrm{Zn}$ in soils, J. Soil Sci. 39 (1988) 15-22.
[4] Anonymous, Les Grandes Productions. Bilan Economique et Social, le Monde, Paris, 1993.

[5] Baize D., Teneurs Totales en Eléments Traces Métalliques dans les Sols, INRA Editions, Paris, 1997.

[6] Benton Jones J. Jr., Plant tissue analysis in micronutrients, in: Mortvedt J.J., Cox F.R., Shuman L.M., Welch R.M. (Eds.), Micronutrients in Agriculture, 2nd ed., SSSA Book series No. 4, Soil Sci. Soc. Am. Madison WI, 1991, pp. 477-521.

[7] Bradford M., A rapid and sensitive method for the quantitation of microgram quantities of proteins utilising the principle of protein-dye binding, Anal. Biochem. 72 (1976) 248-254.

[8] Brown A.L., Jurinak J.J., Effect of liming on the availabilities of zinc and copper, Soil Sci. 98 (1964) 170-173.

[9] Cataldo D.A., Wildung R.E., Soil and plant factors influencing the accumulation of heavy metals by plants, Environ. Health Perspect. 27 (1978) 149-159.

[10] Chaney R.L., Zinc phytotoxicity, in: Robson A.D. (Ed.), Zinc in Soils and Plants, Kluwer Academic Publishers, Dordrecht, 1993, pp. 135-150.

[11] Chaudri A.M., McGrath S.P., Giller K.E., Rietz E., Sauerbeck D., Enumeration of indigenous Rhizobium leguminosarum biovar trifoli in soils previously treated with metal-contaminated sewage sludge, Soil Biol. Biochem. 25 (1993) 301-309.

[12] Chlopecka A., Adriano D.C., Mimicked in situ stabilization of metals in a cropped soil: bioavailability and chemical form of zinc, Environ. Sci. Technol. 30 (1996) 3294-3303.

[13] Clijsters H., Van Assche F., Inhibition of photosynthesis by heavy metals, Photosynth. Res. 7 (1985) 31-40.

[14] De Haan F.A.M., Bourg A.C.M., Brookes P.C., Verstraete W., van Riemsdijk W.H., van der Zee S.E.A.T.M., Giraldez J.V., Soil Quality Assessment. State of the Art Report on Soil Quality, Final report XII523-89, Commission of the European Communities, Luxemburg, 1989.

[15] Didier V., Mench M., Gomez A., Manceau A., Tinet D., Juste C., Réhabilitation de sols pollués par le cadmium: évaluation de l'efficacité d'amendements minéraux pour diminuer la disponibilité du Cd, C. R. Acad. Sci. Paris Sér. III 316 (1993) 83-88.

[16] Giovanoli R., Stähli E., Feitknecht W., Über Oxidhydroxide des vierwertigen Mangans mit Schichtengitter. 1. Mitteilung: Natriummangan (II,III) manganat (IV), Helv. Chim. Acta 53 (1970) 454-464. 
[17] Gworek B., Zinc inactivation in anthropogenic soils by synthetic zeolites, Bull. Pol. Acad. Sci. Biol. Sci. 40 (1992) 205-210.

[18] Hinesly T.D., Alexander D.E., Ziegler E.L., Barett G.L., Zinc and cadmium accumulation by corn inbreds grown on sludge-amended soil, Agron. J. 70 (1978) 425-428.

[19] Juste C., Mench M., Long-term application of sewage sludge and its effects on metal uptake by crops, in: Adriano D.C. (Ed.), Biochemistry of Trace Metals, Lewis Publishers Inc., Boca Raton, FL, 1992, pp. 159-193.

[20] Iskandar I.K., Adriano D.C., Remediation of Soils Contaminated with Metals, Science Reviews, Northwood, 1997.

[21] Lebourg A., Sterckeman T., Ciesielski H., Proix N., Intérêt de différents réactifs d'extraction chimique pour l'évaluation de la biodisponibilité des métaux en traces du sol, Agronomie 16 (1996) 201-215.

[22] Macnicol R.D., Beckett P.H.T., Critical tissue concentrations of potentially toxic elements, Plant Soil 85 (1985) 107-129.

[23] Manceau A., Hargé J.C., Sarret G., Hazemann J.L., Boisset M.C., Mench M., Cambier Ph., Prost R., Direct determination of heavy metal speciation in soils by EXAFS spectroscopy, in: Prost R. (Ed.), Contaminated Soils, INRA Editions, Paris, 1997, pp. 99-120.

[24] McKenzie R.M., The adsorption of lead and other heavy metals on oxides of manganese and iron, Aust. J. Soil Res. 18 (1980) 61-73.

[25] Mench M., Vangronsveld J., Didier V., Clijsters H., Evaluation of metal mobility, plant availability and immobilization by chemical agents in a limed-silty soil, Environ. Pollut. 86 (1994) 279-286.

[26] Mench M., Coussin F., Mocquot B., Bussière S., Prunet T., Lagriffoul A., Evaluation des apports d'un biotest végétal et de la spéciation des éléments traces à la mise au point d'une batterie de tests d'écotoxicologie terrestre applicable aux sols et aux déchets, Rapport final nº4 93 0029, Ademe, Paris, 1996.

[27] Mench M., Vangronsveld J., Lepp N.W., Edwards R., Physico-chemical aspects and efficiency of trace element immobilization by soil amendments, in: Vangronsveld J., Cunningham S.C. (Eds.), MetalContaminated Soils: In Situ Inactivation and
Phytorestoration., Springer-Verlag, Berlin and R.G. Landes Company, Georgetown, TX, 1998, pp. 151-182.

[28] Sappin-Didier V., Utilisation de composés inorganiques pour diminuer les flux de métaux dans deux agrosystèmes pollués : étude des mécanismes impliqués par l'emploi d'un composé du fer, Thèse de Doctorat, Chimie analytique et environnement, Université Bordeaux I, Bordeaux, 1995.

[29] Sylvester E., Manceau A., Dits V.A., The structure of monoclinic Na-birnessite and hexagonal birnessite. Part 2. Results from chemical studies and EXAFS spectroscopy, Am. Mineral. 82 (1997) 962-978.

[30] Uren N., Reisenauer H., The role of root exudates in nutrient acquisition, Adv. Plant Nutr. 3 (1988) 79-114.

[31] Van Assche F., Cardinaels C., Clijsters H., Induction of enzyme capacity in plants as a result of heavy metal toxicity: Dose-response relations in Phaseolus vulgaris L., treated with zinc and cadmium, Environ. Pollut. 52 (1988) 103-115.

[32] Van Assche F., Clijsters H., Effects of metals on enzyme activity in plants, Plant Cell Environ. 13 (1990) 195-206.

[33] Vangronsveld J., Clijsters H., A biological test system for the evaluation of metal phytotoxicity and immobilization by additives in metal contaminated soils, in: Merian E., Haerdi W. (Eds.), Metal Compounds in Environment and Life, 4 (Interrelation between Chemistry and Biology), Science Technology Letters, Northwood, UK, 1992, pp. 117-125.

[34] Vangronsveld J., Colpaert J., Van Tichelen K., Reclamation of a bare industrial area contaminated by non-ferrous metals: physico-chemical and biological evaluation of the durability of soil treatment and revegetation, Environ. Pollut. 94 (1996) 131-140.

[35] Vangronsveld J., Cunningham S.C., MetalContaminated Soils: In Situ Inactivation and Phytorestoration., Springer-Verlag, Berlin and R.G. Landes Company, Georgetown, TX, 1998.

[36] Wong S.T., Cheng S., Synthesis and characterization of pillared buserite, Inorg. Chem. 31 (1992) 1165-1172.

[37] Xu Y., Schwartz F.W., Sorption of $\mathrm{Zn}^{2+}$ and $\mathrm{Cd}^{2+}$ on hydroxyapatite surfaces, Environ. Sci. Technol. 28 (1994) 1472-1480. 